\title{
IMPACT OF SMALL SCALE GOLD MINING ON SOILS OF THE WETLAND FORESTS IN EAST USAMBARA, TANZANIA
}

\author{
C Kweyunga ${ }^{1}$ and RBM Senzota ${ }^{2}$ \\ ${ }^{1}$ Department of Botany, University of Dar es Salaam, P. O. Box 35060, Dar es Salaam, Tanzania \\ ${ }^{2}$ Department of Zoology and Wildlife Conservation, University of Dar es Salaam, P. O. Box \\ 35064, Dar es Salaam, Tanzania
}

\begin{abstract}
Soil pits in disturbed and natural wetland forests of East Usambara were excavated and soil profile samples collected and analysed for physical and chemical properties. Their physical and chemical characteristics were found to be sharply different from those of the surrounding hills. Differences included lack of A Horizon, water saturation, presence of very high organic matter, very low $\mathrm{pH}$ and hence very poor in basic cations, and low microbial activity. Nutrient recycling, especially nitrogen and phosphorus, tended to shift from mineralization to immobilization. Effects of soil disturbance on both physical and chemical characteristics of the soils were also very vivid. The soils disturbed from gold mining possessed an altered soil structure, improper development of soil horizons and removal of organic matter on the surface. Burried A horizons were found in all plots at the disturbed site. Carbon:Nitrogen ratios were significantly higher in the undisturbed forests suggesting greater capacity in carbon sequestration. Both sites existed in the same general area but while the undisturbed one possessed all histosol (organic soil) characteristics, the disturbed site soils were heterogenous and possessed characteristics associated with mineral soils (inceptisols). The present study suggests that disturbance has led into a reduction in the supply capacity of minerals such as nitrogen and phosphorus, and the low supply of such minerals will inhibit regrowth of the natural vegetation.
\end{abstract}

\section{INTRODUCTION}

The East Usambara Highlands in Tanzania are part of a chain of the ancient Eastern Arc Mountains found in East Africa. Owing to their old age (about 200 million years old), the mountains have unique biodiversity and high level of endemism in the forests they harbour and there has been much scientific interest in them; a number of studies have been conducted on their plants and animals (Hamilton and Bented-Smith 1989). However, little has been done on the wetland forests. Although the wetland forests form a small fraction of the total vegetation in the East Usambaras, they constitute a unique and important habitat. They have a unique plant and animal composition and are of paramount importance in the provision of ecosystem systems such as water preservation and purification for the human and other biota in the surrounding highlands and lowlands (Senzota 2004). The main land use categories in the highlands are forest protection, human settlements, farming and tea estates (Hamilton and Benten-Smith 1989, Mashauri 2004).

Joseph (1991) and Mruma and Kinabo (2004) examined geological aspects of the East Usambaras and some detailed assessments have been made on the soils in a number of the regular (non wetland) Forest Reserves (Milne 1937, Anderson 1963, Anon 1986, Shaka and Msangi 1996, Shaka and Mwanga 1996, Shaka et al. 1996). To our knowledge, there has been no detailed study on the soils of the wetland forests in the East Usambaras. In addition, no studies have been carried out in areas subjected to soil disturbances such as through gold mining and how this would affect soil characteristics and vegetation of affected areas.

The present study aimed at identifying and documenting the physical and chemical properties of the soils in the wetland forests. 
The study further looked into the impact on the soils that was caused by gold mining activities which started in October 2003 and which took place exclusively in the wetland forests (Senzota 2004).

\section{MATERIALS AND METHODS}

This study was conducted at two wetland forests in February 2006. The first site, Monga site, is situated at $05^{\circ} 05.92 \mathrm{~S}$, $38^{\circ} 35.14 \mathrm{E}$ and 990 masl; the second, Jangili site, is at $05^{\circ} 05.17 \mathrm{~S}, 38^{\circ} 35.32 \mathrm{E}$ and 1082 masl. Each site is surrounded by hills of varying gradients that were mostly covered by patches of forest, tea estates and cultivated crops. At each site, the relief is almost level; the parent material is sandstone.

Monga site is a natural wetland forest having a mixture of trees and herbaceous hydrophytes. The Jangili site is also a wetland that was formally similarly forest covered but had now been disturbed by gold mining activities which started in October 2003 (Senzota 2004).

At each site, three soil pits were dug (approx. $20 \mathrm{~m}$ apart) and soil profile data collected. At the Jangili site a fourth soil pit (Jangili X) was dug at an adjacent foot hill (gradient approximately 30\%) and similar data collected. In addition, a $20 \mathrm{~cm}$ x $20 \mathrm{~cm}$ soil tassera (sensu Jenny 1980) was excavated from the top $10 \mathrm{~cm}$ at one of the Monga site plots (Monga III). The tassera was taken in order to have baseline reference on the top layer in an undisturbed state of the wetland soils of East Usambara.

Some soil characteristics such as profile depths, soil texture and $\mathrm{pH}$ readings were taken in the field. From each pit, wet soil samples, weighing approximately $250 \mathrm{~g}$ each, were collected from each of the profile horizon, preserved in tightly closed polythene bags and transported to the laboratory for physical and chemical analyses. Other chemical data were determined, on the soil samples collected in the field, at the laboratory in the Department of Botany, University of Dar es Salaam. Statistical comparisons employed the Mann -Whitney $U$ test for differences in soil components between Monga and Jangili sites and the Wilcoxon Signed Rank Test for differences of the A horizon Organic Matter between the two sites and the Jangili $\mathrm{X}$ soil pit.

Soil texture $($ silt $=2-20 \mu \mathrm{m}$, clay $<2 \mu \mathrm{m})$ was determined by using the pipette method as described by Gee and Bauder (1986). The resulting data are presented as percent sand, silt and clay; texture was inferred from the International Soil Science Society System (ISSSS) textural classification system (Gee and Bauder 1986).

Soil $\mathrm{pH}$ was measured electrometrically using a metrohm E510 pH meter. This was done using a 1:1 soil: water mixture that was allowed to equilibrate for 30 minutes (McLean 1982). The $\mathrm{pH}$ of the stirred suspension was read from the $\mathrm{pH}$ meter. Soil organic carbon was determined by the Walkley-Black potassium dichromate method and the organic matter content was obtained by multiplying the organic carbon concentration by 1.72 (Nelson and Sommers 1982, Allen 1989).

Available soil phosphorus was extracted using the Olsen and Kurtz method as described by Olsen and Sommers (1982) and Emteryd (1989). Ortho-phosphate was determined colorimetrically using a spectrophotometer according to the ascorbic acid method (Allen 1989, Olsen and Sommers 1982). The amount of phosphorus in the sample was obtained from the calibration curve of standard $\mathrm{PO}_{4}^{-}$. Total soil nitrogen was determined using a semi-micro Kjeldahl digestion (Bremner and Mulvaney 1982, Allen 1989, Emteryd 1989) and colorimetric determination of the resultant ammonium by colour reaction (Endo-phenol blue method) (Allen 1989). 
Preliminary investigations had indicated that the soils were acidic and hence the lithium saturating solution at $\mathrm{pH} 8.2$ was used in the determination of Cation Exchange Capacity (CEC) following the method by Rhoades (1982) and Emteryd (1989) using an Atomic Absorbance Spectrometer (AAS), Perkin Elmer 3100.

\section{RESULTS}

Soil profile observations, physical and chemical analyses indicated that the undisturbed wetland forest at the Monga site had soils that were heavily humic (Fig. 1). At the $0-40 \mathrm{~cm}$ depth, reactions with Hydrogen peroxide left a solution containing organic acid derivatives (sensu Allen 1989). Although no further analysis was conducted the solutions would contain mainly various lignin and cellulose products, both of which are very resistant to oxidation by Hydrogen peroxide (Allen 1989). This contrasts sharply with the situation in the disturbed wetland forest at the Jangili site where the mining activity removed the histic A horizon and instead the top soils were dominated by sand and gravel imported from $\mathrm{C}$ horizon and a buried $\mathrm{A}$ horizon was prevalent at the depth of $40-90 \mathrm{~cm}$ (Fig. 1; Table 1). At both sites, the soils were generally deep (Table 1; sensu Shaka and Mwanga 1996).

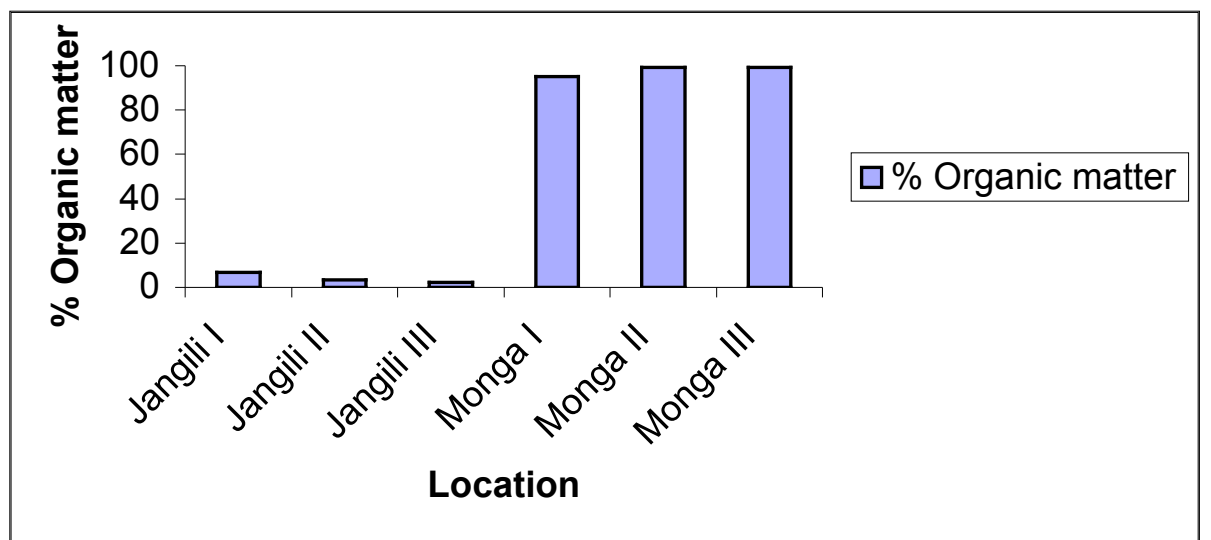

Figure 1: Accumulation of organic matter in Monga and Jangili top $(0-10 \mathrm{~cm})$ soils. The gold mining activity removed the histic A horizon at the Jangili site. East Usambara, Tanzania. February 2006.

Table 1: Soil horizon depths in the wetland forests at Monga (natural forest) and Jangili (disturbed from gold mining). East Usamabara, Tanzania, 2006. (- = absent; bA = buried A horizon)

\begin{tabular}{llllll}
\hline Site & & \multicolumn{4}{c}{ Horizon depth (cm) } \\
\hline & Mull & A & B & BA & C \\
\hline Monga I & $0-30$ & $30-60$ & $60-120$ & - & $120+$ \\
Monga II & $0-60$ & - & $60-110$ & - & $110+$ \\
Monga III & $0-140$ & $140-200$ & $200-230$ & - & $230+$ \\
Jangili I & - & $0-80$ & - & $80-120$ & $120+$ \\
Jangili II & - & $0-30$ & $30-80$ & $80-120$ & $120+$ \\
Jangili III & - & $0-10$ & $10-50$ & $50-90$ & $90+$ \\
Jangili X & - & $0-10$ & $10-100$ & - & $100+$ \\
\hline
\end{tabular}


There was some heterogeneity within the undisturbed Monga site. In pit I of the site, the submerged part at the depth of $50-60$ $\mathrm{cm}$ contained decomposed material, mostly buried alluvial sediment that might have come from the surrounding hills and perhaps from the nearby Tea Estate. Also, at the depth of $60-80 \mathrm{~cm}$, a breached horizon (Ae horizon) was apparent that had soil dominated by sand fractions; the sand fraction was the most variable of all physical parameters $(\mathrm{CV}=171.3 \%$; Table 2$)$. In pit III of the site, the profile was $100 \%$ humic up to $140 \mathrm{~cm}$ deep. While in the other pits water content and water filled pore space were low in the upper $0-30 \mathrm{~cm}$ depth, there was no variation in pit II where water content and water filled pore space were uniform throughout the profile at $80 \%$ and $95 \%$ respectively. Thus this pit was submerged in water even late in the dry season (February 2006) of what was a relatively very prolonged dry season. For all the three plots in this site, clay accumulations and greying were common at the depth of $80-200 \mathrm{~cm}$.

Table 2: $\quad$ Statistical differences of soil components between Monga and Jangili sites. East Usambara, Tanzania; February 2006. ns = not significant; * = weak; ** = significant; $* * *=$ very significant. $\mathrm{N}=3$ soil pits

\begin{tabular}{|c|c|c|c|c|c|}
\hline Component & Site & Mean & $\mathrm{CV}$ & $\mathrm{P}$ & Strength \\
\hline \multirow[t]{2}{*}{ Sand } & Monga & 8.20 & 171.3 & 0.0028 & $* * *$ \\
\hline & Jangili & 24.20 & 82.4 & & \\
\hline \multirow[t]{2}{*}{ Silt } & Monga & 5.50 & 97.9 & 0.001 & $* * *$ \\
\hline & Jangili & 27.50 & 84.6 & & \\
\hline \multirow[t]{2}{*}{ Clay } & Monga & 59.20 & 68.8 & 0.4679 & Ns \\
\hline & Jangili & 49.10 & 56.1 & & \\
\hline \multirow[t]{2}{*}{ Water } & Monga & 81.20 & 27.2 & 0.0127 & $* *$ \\
\hline & Jangili & 49.50 & 58.4 & & \\
\hline \multirow[t]{2}{*}{ WFPS } & Monga & 88.80 & 12.4 & 0.0062 & $* * *$ \\
\hline & Jangili & 70.20 & 23.8 & & \\
\hline \multirow[t]{2}{*}{$\mathrm{PH}$} & Monga & 4.50 & 10.4 & 0.0015 & $* * *$ \\
\hline & Jangili & 5.20 & 7.0 & & \\
\hline \multirow[t]{2}{*}{ Available P } & Monga & 1.96 & 93.0 & 0.1321 & Ns \\
\hline & Jangili & 0.62 & 44.9 & & \\
\hline \multirow[t]{2}{*}{$\mathrm{Na}$} & Monga & 0.63 & 118.2 & 0.9725 & Ns \\
\hline & Jangili & 0.38 & 71.8 & & \\
\hline \multirow[t]{2}{*}{ K } & Monga & 3.23 & 77.5 & 0.8094 & Ns \\
\hline & Jangili & 2.91 & 42.4 & & \\
\hline \multirow[t]{2}{*}{$\mathrm{Ca}$} & Monga & 8.87 & 72.5 & 0.1321 & Ns \\
\hline & Jangili & 16.00 & 73.3 & & \\
\hline \multirow[t]{2}{*}{$\mathrm{Mg}$} & Monga & 4.53 & 117.7 & 0.1517 & Ns \\
\hline & Jangili & 5.26 & 72.5 & & \\
\hline \multirow[t]{2}{*}{ CEC } & Monga & 63.00 & 47.1 & 0.8633 & Ns \\
\hline & Jangili & 68.40 & 33.1 & & \\
\hline \multirow[t]{2}{*}{ Ammonia $\mathrm{N}$} & Monga & 3.26 & 64.2 & 0.0101 & $* *$ \\
\hline & Jangili & 1.16 & 110.1 & & \\
\hline \multirow[t]{2}{*}{ Nitrate $\mathrm{N}$} & Monga & 3.91 & 58.7 & 0.0197 & $* *$ \\
\hline & Jangili & 1.46 & 88.0 & & \\
\hline \multirow[t]{2}{*}{ Organic C } & Monga & 28.70 & 100.5 & 0.0430 & $* *$ \\
\hline & Jangili & 7.47 & 154.8 & & \\
\hline \multirow[t]{2}{*}{ Total N } & Monga & 1.15 & 80.2 & 0.1145 & Ns \\
\hline & Jangili & 0.59 & 155.6 & & \\
\hline \multirow[t]{2}{*}{$\mathrm{C} / \mathrm{N}$} & Monga & 22.26 & 55.4 & 0.0197 & $* *$ \\
\hline & Jangili & 11.57 & 11.0 & & \\
\hline \multirow[t]{2}{*}{ Microbes } & Monga & 211.95 & 267.8 & 0.1321 & Ns \\
\hline & Jangili & 438.34 & 164.0 & & \\
\hline \multirow[t]{2}{*}{ OM } & Monga & 49.36 & 100.5 & 0.0430 & $* *$ \\
\hline & Jangili & 12.86 & 154.8 & & \\
\hline
\end{tabular}




\begin{tabular}{llllll} 
A Horizom OM & Monga & 31.45 & 114.6 & 0.0313 & $* *$ \\
& Jangili X & 2.98 & 127.5 & & $*$ \\
A Horizon OM & Jangili & 7.14 & 105.9 & 0.0625 & $*$ \\
& Jangili X & 2.98 & 127.5 & & \\
\hline
\end{tabular}

Table 3: Levels of exchangeable bases and Cation Exchange Capacity (CEC) in the different soil horizons at the natural (Monga) and disturbed (Jangili) wetland forests in Eastern Usambara, Tanzania. February 2006. (levels sensu Shaka and Mwanga 1996). $*$ Low; $\quad * *=$ Medium; $\quad * * *=$ High; $\quad * * * *=$ Very high; bA $=$ buried A horizon. - = not applicable

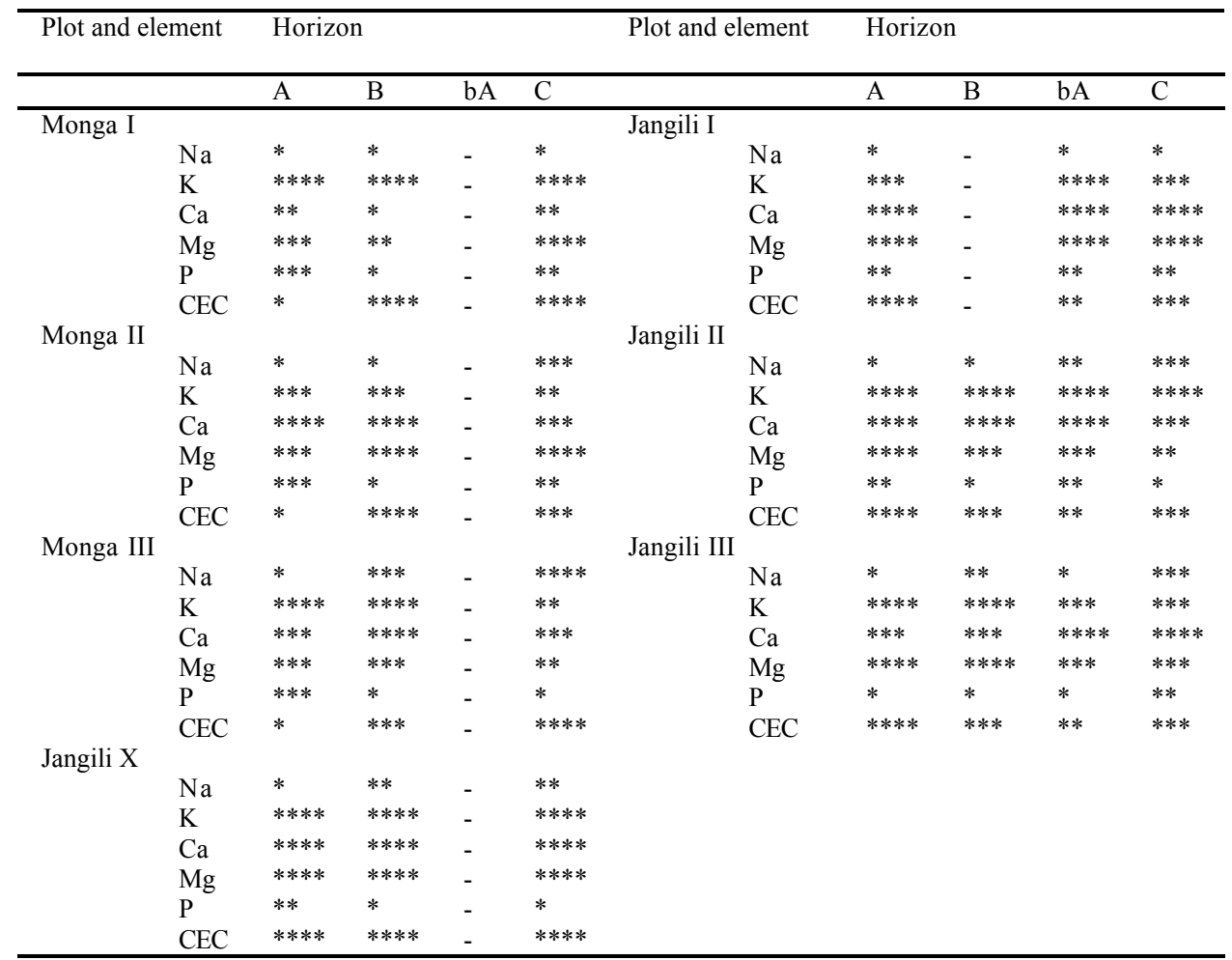

At the Jangili site, water content was much lower than that at the Monga site, except for pit III which had water saturation at the upper depth of $10-20 \mathrm{~cm}$. The profile in the slightly higher elevation at the periphery of Jangili site (Jangili X) contrasted sharply with both the Monga site and Jangili site pits in that it exhibited characteristics of oxisols (Tables 2 and 3 ).

Ammonium nitrogen was relatively high (4 $-8 \mathrm{mg} / 100 \mathrm{~g}$ ) in the mid horizons at the
Monga site; it was also high $(4.53 \mathrm{mg} / 100$ $\mathrm{g})$ in the upper horizon of pit II at the site. For all the pits at the disturbed Jangili site ammonium nitrogen was low (mostly $<1$ $\mathrm{mg} / 100 \mathrm{~g}$; Fig. 2). Except for Monga II, nitrate nitrogen was high down the profile, suggesting leaching of $\mathrm{NO}^{-3}$ from the upper horizons where mineralization would normally occur. As expected, total nitrogen tended to decrease down the profile. Overall, the undisturbed soils had significantly $(\mathrm{P}<0.02)$ higher levels of both reduced 
(Ammonia) and oxidized (nitrates/nitrites) nitrogen (Table 2).

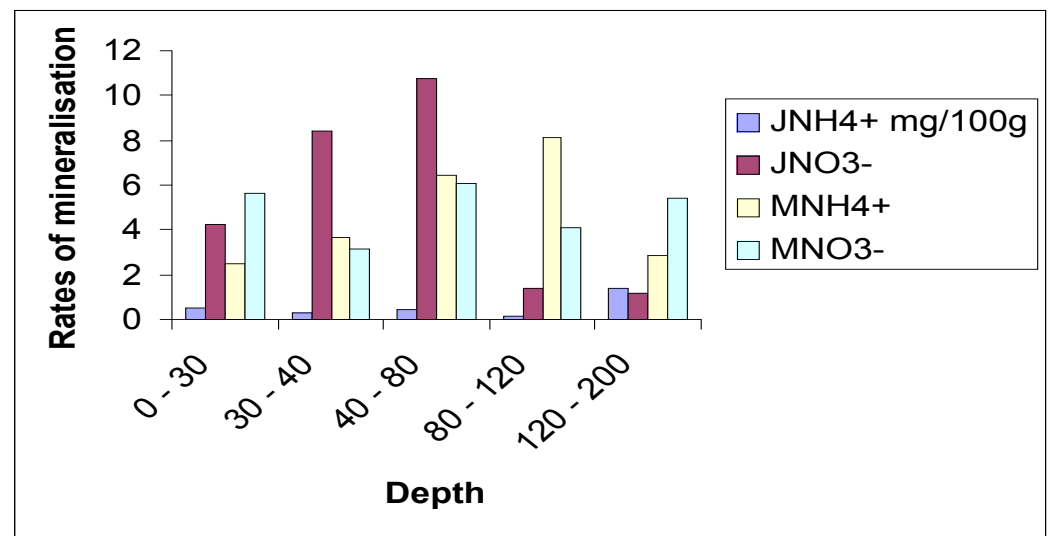

Figure 2: $\quad$ Mineralisation $(\mathrm{mg} / 100 \mathrm{~g})$ of nitrogen in different depths at Monga (M) and Jangili (J) sites. Note that mineralisation of nitrogen at Monga exists mostly in a reduced form $\left(\mathrm{NH}_{4}{ }^{+}\right)$and oxidised form $\left(\mathrm{NO}_{3}{ }^{-}\right)$due to water saturation. At Jangili, the oxidised form $\left(\mathrm{NO}_{3}{ }^{-}\right)$predominated. East Usambara, Tanzania. February 2006.

Both organic carbon and organic matter were very high $(50-60 \%)$ in top and subsoils at the Monga site; they were significantly $(\mathrm{P}=0.043)$ lower at the Jangili site (Table 2). Similarly, the $\mathrm{C}: \mathrm{N}$ values were high with $>20$ values being common; the values at the disturbed Jangili plots were average and significantly $(\mathrm{P}<0.02)$ lower (Table 2$)$. Microbial populations (expressed as $\mathrm{TPF} / \mathrm{Kg}$ $\left.24 \mathrm{~h}^{-1}\right)$ were high $(>1000)$ in all unsaturated upper soils at both Monga and Jangili sites; the populations were sharply lower down the profiles and in the whole of the submerged pit II at the Monga site thus giving very high levels of coefficient of variation (CV) $(\mathrm{CV}=268$ for Monga pits and 164 for Jangili pits; Table 2; Fig. 3).

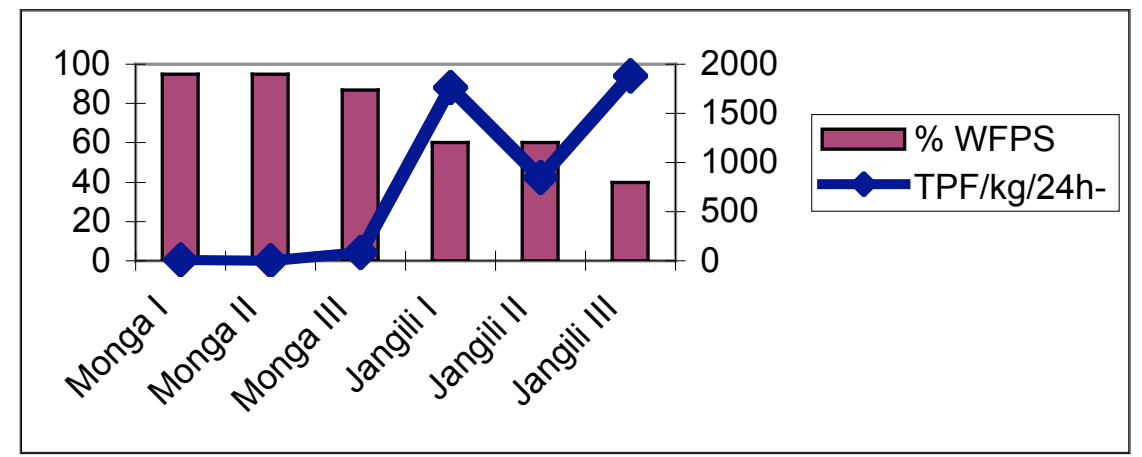

Figure 3: Effect of water saturation (left axis) on the microbial population (right axis) at Monga. Note that the saturated soils of Monga have low $\mathrm{TPF} / \mathrm{kg} / 24 \mathrm{~h}^{-1}$. East Usambara, Tanzania. February 2006.

The soils at both sites were acidic with $\mathrm{pH}$ ranging from 3 to 5.8; however, those at the 
undisturbed Monga site were significantly $(\mathrm{P}=0.0015)$ more acidic than those at the disturbed Jangili site (Table 2). Available phosphorus was high in the upper horizons and tended to decrease down the soil profile at the undisturbed Monga site. It was medium to low at the disturbed Jangili site where also the values tended to be variable along the profiles (Table 3; Fig. 4).

Table 4: $\quad$ Some chemical characteristics of a soil Tassera $(0-10 \mathrm{~cm})$ collected from Monga plot III. All cations are expressed as meq/100g samples and phosphorus in $\mathrm{mg} / 100 \mathrm{~g}$ oven dry weight. East Usambara, Tanzania. February 2006. SD = Standard deviation; $\mathrm{CV}=$ Coefficient of Variation.

\begin{tabular}{lllllllllll}
\hline $\begin{array}{l}\text { Depth } \\
(\mathrm{cm})\end{array}$ & $\mathrm{PH}$ & $\% \mathrm{C}$ & $\% \mathrm{~N}$ & $\mathrm{P}$ & $\mathrm{K}$ & $\mathrm{Na}$ & $\mathrm{Ca}$ & $\mathrm{Mg}$ & $\mathrm{C.E.C}$ & $\mathrm{C}: \mathrm{N}$ \\
\hline $0-1$ & 4.8 & 55.35 & 3.26 & 49.7 & 15.3 & 5.2 & 55.2 & 53.4 & 280 & 17.0 \\
$2-3$ & 4.7 & 56.72 & 3.51 & 52.8 & 10.1 & 3.2 & 56.8 & 50.8 & 269 & 16.2 \\
$4-5$ & 4.5 & 45.72 & 2.98 & 53.6 & 11.2 & 4.6 & 58.4 & 54.4 & 280 & 18.7 \\
$5-6$ & 4.5 & 54.14 & 3.14 & 52.9 & 16.8 & 4.4 & 58.0 & 53.4 & 282 & 17.2 \\
$6-7$ & 4.7 & 54.19 & 2.56 & 52.6 & 18.3 & 4.1 & 58.6 & 56.8 & 280 & 21.2 \\
$7-8$ & 4.5 & 54.31 & 2.71 & 51.8 & 19.7 & 2.8 & 55.1 & 56.9 & 279 & 20.0 \\
$9-10$ & 4.6 & 55.26 & 3.14 & 53.2 & 20.4 & 2.6 & 55.0 & 52.4 & 285 & 17.6 \\
Mean & 4.6 & 53.67 & 3.04 & 52.4 & 16.0 & 3.8 & 56.7 & 54.0 & 279 & 18.27 \\
SD & 0.122 & 3.623 & 0.335 & 1.302 & 4.027 & 0.986 & 1.628 & 2.233 & 4.957 & 1.796 \\
\% CV & 2.6 & 6.8 & 10.7 & 2.5 & 25.2 & 25.7 & 2.9 & 4.1 & 1.8 & 9.8 \\
\hline
\end{tabular}

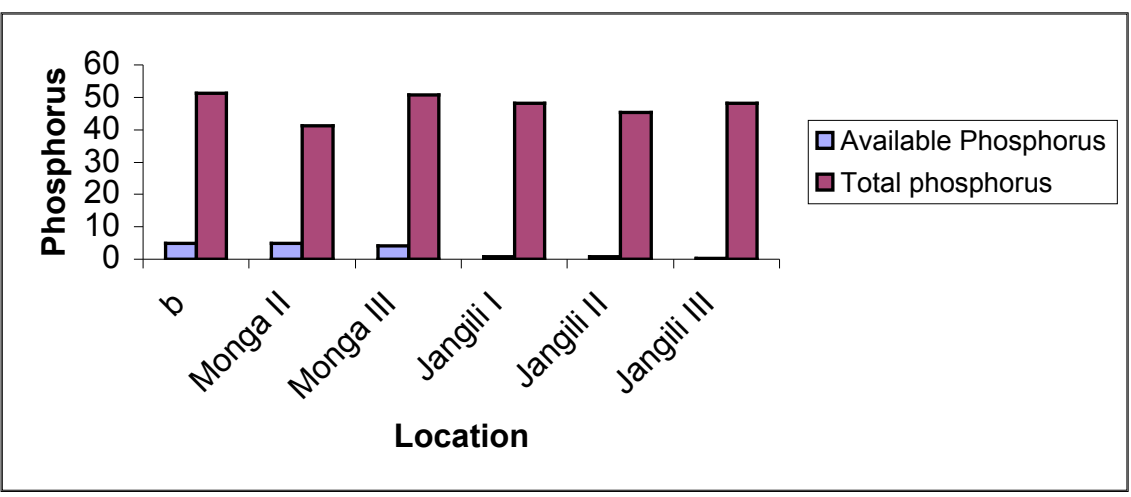

Figure 4: Total and available phosphorus $(\mathrm{mg} / 100 \mathrm{~g})$ in the wetland forests at Monga (mostly organic soils) and Jangili (mostly mineral soil; organic matter $<2 \%$ ). Note that available phosphorus is higher in the organic soils at Monga than in the mineral soils where there is fixation by aluminium and iron. East Usambara, Tanzania. February 2006.

The $20 \times 20 \mathrm{~cm}$ soil block taken from the $10 \mathrm{~cm}$ topsoil at Monga exhibited, strongly, characteristics of a histsol. There was high nutrient reserve in the tassera whereby the values of nitrogen, phosphorus and potassium (NPK) were very high at $3 \%$, $52.4 \mathrm{mg} / 100 \mathrm{~g}$ and $16.0 \mathrm{meq} / 100 \mathrm{~g}$ respectively. Values of exchangeable bases were also high and the $\mathrm{C}: \mathrm{N}$ ratios were moderate $($ Mean $=18.27 ; \mathrm{CV}=9.8 \%$; Table 4).

Exchangeable bases were variable but medium to high on the average. Cation 
Exchange Capacity was low in the upper horizon of Monga pits; it was high in the other horizons in the site and in all the horizons at the disturbed Jangili site (Table 3). At the Monga site, seepage water (into the soil pit) exhibited high levels of both reduced and oxidized nitrogen, suggesting leaching of nitrates from the upper unsaturated horizon where mineralization and oxidation processes would occur. At the Jangili site the values of reduced nitrogen (Ammonium nitrogen) were low.

\section{DISCUSSION}

Physical and chemical characteristics of soils at both Monga (undisturbed) and Jangili (disturbed) sites suggest both to be typical wetlands. Water saturation of $80-90 \%$ observed at the Monga site would be a serious impediment to organic matter decomposition because of low aeration; hence the thick humic layer that accumulated there. The low microbial population (Fig. 3) suggests loss of oxidizing bacteria in the water-saturated soils. Accumulation of organic matter and presence of partially oxidized products also alter the soil $\mathrm{pH}$ which in turn creates unconducive condition for microbial growth and activity. The low $\mathrm{pH}$ at both Jangili and Monga sites are likely a result of formations of partially oxidised organic acids (Brady and Weil 1999, Allen 1989).

Soil tassera data indicated that large amounts of nutrients were held in undecomposed organic residues; for example, nitrogen was very high $(3 \%)$ and phosphorus was ten times the amount of phosphate (mineralized phosphorus in the soils) that was therefore available to the plants. An advantage of slow decomposition of organic matter is that there would be slow loss of mineral nutrients from the area through leaching and water runoff. Large amounts of organic matter had accumulated at the undisturbed Monga site where the upper horizon was as much as $99 \%$ organic matter, suggesting completely histic conditions (Fig. 1). Normal soils have an average of $2 \%$ organic matter (Young 1976). Organic matter is important in the preservation of soil structure and plant nutrient supply; its positive role in carbon sequestration has recently been reemphasised (Swift 2001, Rawls et al. 2003, Martin et al. 2006).

The high water saturation also meant that only plants adapted to surviving in the poor aeration situation could grow there. Typical plants included the herbs Scleria and Cyperus papyrus and the tree Voacanga africana (Senzota 2004, Senzota and Mbago 2006). C. papyrus uses the $\mathrm{C}_{4}$ photosynthetic pathway that is significantly more efficient than the $\mathrm{C}_{3}$ pathway. $V$. africana possesses pneumatophores that allow transfer of air into the roots in the saturated soil.

An important question is "how effectively are the nutrients retained by the wetlands?" Soil tassera data indicated that large amounts of nutrients were held up and the amount released, upon mineralization, would be of great importance in quantifying loss and gain. We postulate that most of the released nutrients would be wasted through leaching and water run off during the rain season. Adsorption of insoluble minerals in the lower horizon was apparent in that $\mathrm{Ca}^{2+}$, for example, tended to be high in lower horizons even though the low $\mathrm{pH}$ values would not favour basic cations. Further sampling during the wet season will enlighten more on the question of nutrient retention rates in these wetland forests.

In the breakdown of organic matter, resulting in mineralization, fungi dominate the first stage process and bacteria come in at a later stage (Chefetz et al. 1996). The successive breakdown of proteins produces simpler substances until eventually ammonia and its salt derivatives are formed. In poorely aerated soils, such as the waterlogged soils, the Amonium nitrogen form $\left(\mathrm{NH}_{4}^{+}-\mathrm{N}\right)$ dominated the Nitrate nitrogen form $\left(\mathrm{NO}_{3}^{-}-\mathrm{N}\right)$ indicating that 
nitrogen existed mostly in the reduced form (Fig. 2). In these wetlands, any ammonium produced would have leached out from the surface aerated histic layer into watersaturated soils down the profile. The ammonium nitrogen is readily fixed by soil colloids resulting in an appreciable accumulation of ammonium down the profile thus making it unavailable to plants. This would result in conditions where nitrogen fails to complete its normal cycle through green plants (see also Brady and Weil 1999). However, some hydrophitic plants can make use of nitrogen in the form of $\mathrm{NH}_{4}^{+}$thus helping to complete the nitrogen cycle (Mitsch and Gosselink 2000). The processes of nitrification and denitrification though diametrically opposed can proceed simultaneously in the soil mass if aeration is patchy (Brady and Weil 1999). A water-logged soil, similar to that at the undisturbed Monga site, is poorly aerated and denitrification readily occurs in saturated soils a few centimetres below the surface. It is now clearly recognised that chemical reduction of nitrates occurs long before the saturation point is reached. Lowery et al. (1996) indicated that the critical moisture content above which denitrification is able to occur is as low as $60 \%$ of water holding capacity of a normal soil. It is likely therefore that loss of nitrogen through denitrification at the undisturbed Monga and disturbed Jangili sites was high since the WFPS reached 95\%. Denitrification is known to be a significant path of loss of nitrogen in wetlands including forested wetlands (Mitsch and Gosselink 2000).

Since nitrates are readily soluble they can be removed by drainage (leaching) and in this way become a complete loss. The main way in which nitrogen can be immobilised and conserved is by uniting it with carbon; Monga site histic soils in the upper horizon and those of the buried A horizon at the Jangili site had good status of nitrogen.

In temperate soils, the $\mathrm{C}: \mathrm{N}$ ratio is established at the values of between 10 and
12, but in tropical soils the figure is much more variable (Brady and Weil 1999) and values as high as 20 have been recorded for some soils carrying high savannah grass (Young 1976). Similar values were recorded in the present study. With respect to C:N ratios the Monga site soils were generally poor quality while those at Jangili site can be considered good quality (Shaka and Mwanga 1996). Whatever the equilibrium point to which the ratio moves, further decomposition would result in the simultaneous loss of carbon and nitrogen in similar proportions. Carbon is continually being lost through oxidation to carbon dioxide. In actual practice the problem of nitrogen conservation in the aerated histic horizon (such as those at Monga and Jangili sites) would be translated into the problem of carbon conservation and, within reason, it may be said that if one can take care of the carbon then the nitrogen will take care of itself. So the relatively high status of nitrogen at the undisturbed Monga site is likely maintained by the bulk of organic carbon that has accumulated largely due to slow decomposition while the loss of nitrogen at the disturbed Jangili site is likely the result of loss of organic layer following the mining activity. Loss of leached nitrate in the lower horizon is likely to be minimum since plants adapted to the water saturated soil, such as $V$. africana, would readily absorb the nitrate in lower horizon owing the plant's adaptive features which include pneumatophores that allow plants to transport $\mathrm{O}_{2}$ down to their roots. We are tempted to put forward the following three postulates.

i) The high content of organic carbon in the upper horizon and buried A horizon ensure continued supply of nitrogen in all forms.

ii) Nitrates formed in the upper histic horizon are absorbed by deep-rooted tree species such as $V$. africana in deeper horizon after leaching.

iii) Ammonium produced due to poor aeration is absorbed by hydrophytes such as 
Typha capensis and Cyperus papyrus that are likely to use the nitrogen in the form of $\mathrm{NH}_{4}^{+}$, and once immobilised into plant tissue the nitrogen cycle would proceed normally. C. papyrus is a known $\mathrm{C}_{4}$ plant that has a higher nitrogen-use efficiency and that is widespread in the oligotrophic wetlands in East Africa (Jones 1988).

Phosphorus availability is also an important area of concern. Soluble phosphates quickly change into less soluble forms when in contact with soil (Brady and Weil 1999, Buresh et al. 1997). Phosphorus held in organic form can be mineralised and immobilized by the same general processes that release nitrogen from soil organic matter. The bulk of the soil phosphorus exists mainly as organic phosphorus, calcium bound inorganic phosphorus and iron or aluminium bound inorganic phosphorus (Fares 1974, Brady and Weil 1999) The iron and aluminium forms are the most common in acidic soils such as those at the wetlands studied. The principal pathways by which phosphorus is lost from the soil system are plant removal, erosion of phosphorus carrying soil particles and phosphorus dissolved in surface run off water. We sampled when it was dry, and since rain season data are not available it is too early to ascertain which process govern the losses of phosphorus. Phosphorus absorbed by plant in both undisturbed and disturbed soils would be returned into soil through the process of immobilization and mineralization mostly occurring in the upper histic horizon. Fixation, after mineralization, is taking place in the lower part where clay accumulation has taken place, and where there is presence of much iron and aluminium due to low $\mathrm{pH}$.

More loss of phosphorous was found in the Jangili disturbed site than at the Monga undisturbed site even though the difference was statistically insignificant (Table 3; Fig. 4). The accelerated loss of soluble phosphorus at Jangili likely resulted from soil disturbance after gold mining activities carried out before we sampled (Senzota 2004). The undisturbed Monga soils contained substantial phosphorus and soil organic matter. Most of the phosphorus taken up by the plants would have been released from the decomposing residues of other plants. Very little is lost as long as the system remains undisturbed. Once the land is cleared or excavated, as was the case at Jangili, organic layer is lost or buried, and loss of phosphorous by runoff water is increased. It is predicted from comparison with the tassera data collected at the Monga site, that within just a few years the system in Jangili will lose most of the phosphorous that had cycled between the plants and the soils before land was degraded. What remained at Jangili was inorganic phosphorous in the soil which mostly existed in the form that is unavailable for plant uptake (Fig. 4). The lower horizon, rich in iron sulphate, was exposed on the upper surface horizon thus forming the yellow red colour that is typical of exposed material rich in iron sulphate. In this manner, the phosphorus supplying capacity of the disturbed soil was rapidly becoming so low that re-growth of natural vegetation will likely be much inhibited. As noted for the other forested parts in the East Usambara, removal of the trees would result into disappearance of the organic matter which accounts for the main nutrient capacity of the soil and re-establishment of trees and the natural forest then becomes most unlikely (Hamilton 1989).

\section{ACKNOWLEDGEMENTS}

We thank F. Mbago, T. Ndunguru, R. Ngunda, R. Chando, I. Mtunguja, A. Chamshama and A. Mkongeo for assistance in the field. We thank the administration and staff of Amani Nature Reserve for logistics assistance and overall support. We thank the Department of Botany for assisting in the analysis of soil samples. We appreciate the comments of anonymous reviewers which greatly improved the quality of our paper. This study was funded by the University of Dar es Salaam - 
MacArthur project for which we are very greatful.

\section{REFERENCES}

Allen ES 1989 Chemical analysis of ecological material. Blackwell Scientific Publications, Oxford.

Anderson GD 1963 A comparison of red and yellowish-red slope soils of the Eastern Usambara foothills, Tanganyika. Afr. Soils 8: $431-434$

Anon. 1986 Soils of Kwamkoro and Bulwa Tea Estates. Report prepared for the Commonwelth Development Corporation, National Soil Service, Mlingano, Tanzania.

Brady NE and Weil RR 1999 The nature and properties of soils. Prentice Hall, New York.

Bremmer JM and Mulvaney CS 1982 Total nitrogen. In: Page AL (Ed.) Methods of soil analysis. Part 2: Chemical and microbiology properties. Agronomy monograph no. 9 (second edition). Madison, USA, pp. $595-624$.

Buresh RJ, Smithoson PC and Hellums DT 1997 Building soil phosphorus capital in Africa. In: Buresh RJ, Sanchez PA and Calhoum F (Eds) Replenishing soil fertility in Africa. Special publication no 51, Soil Science Society of America, Madison, Wisconsin.

Chefetz B, Hatcher P, Hadar Y and Chen Y 1996 Chemical and biological characterization of organic matter during compositing of municipal solid waste. J. Environ. Qual. 25:776 - 785.

Emteryd O 1989 Chemical and physical analysis of inorganic nutrient in plant, soil, water and air. Stencil No. 10. Department of Forest, Swedish University of Agriculture.

Fares F 1974 Quantitative survey of organic phosphorus in different soil types: phosphorus in agriculture. American Society of Agronomy, Madison, Wisconsin.

Gee GW and Bouder JW 1986 Particle-size analysis. In: Klute A (Ed.) Methods of soil analysis. Part 1: Physical and mineralogical methods. Agronomy monograph No.9. Modison, Wisconsin, U. S. A., pp. $383-411$.

Hamilton AC 1989 Soils. In: Hamilton AC and Bented-Smith R (Eds) Forest conservation in the East Usambara Mountains. IUCN, Gland, pp. $87-96$.

Hamilton AC and Bented-Smith R 1989 (Eds). Forest conservation in the East Usambara Mountains. IUCN, Gland.

Jenny H 1980 The soil resource: origin and behaviour. Ecological Studies Series 37. Springer Verlag, New York.

Jones MB 1988 Photosynthetic responses of $\mathrm{C}^{3}$ and $\mathrm{C}^{4}$ wetland species in a tropical swamp. J. Ecol. 76: 253 - 262.

Joseph SM 1991 Chemistry and mineralogical studies of the Amani Bauxite deposit, Tanga Region, Northeast Tanzania. M.Sc. Thesis, University of Dar es Salaam.

Lowery BMA, Arshad RL and Jones WJ 1996 Methods for assessing soil quality. SSSA Special Publication 49, Madison, Wisconsin.

Martin M, Celi L, Bonifacio E, Nardi S and Barberis E 2006 Charasteristics of soil organic matter in a limnic histosol of the alpine morainic system. Soil Sc. 171: $527-540$

Mashauri S 2004. Land use in the East Usambara Mountains. In: Nikundiwe AM, Kabigumila JDL, Magingo FSS and Senzota RBM (Eds) Ecological Monitoring in the East Usambara Mountains: Proceedings of the second workshop. Departments of Botany/Zoology and Marine Biology, University of Dar es Salaam, Tanzania, pp. $5-31$.

McLean EO 1982 Soil pH and lime requirements. In: Page AL (Ed.) Methods of soil analysis. Part 2: Chemical and microbiology properties. Agronomy monograph no. 9 (second edition). Madison, pp. $199-224$.

Milne G 1937 Essays in applied pedology, 1. Soil type and management in relation 
to plantation agriculture in East Usambara. E. Afr. Agric. J. 3: 7 - 20.

Mitsch WM and Gosselink JG 2000 Wetlands. John Wiley \& Sons, Inc, New York.

Mruma AH and Kinabo C 2004 Geology, mineral resources potential and environmental impact due to mining in the East Usambara Mountains, Tanzania. In: Nikundiwe AM, Kabigumila JDL, Magingo FSS and Senzota RBM (Eds) Ecological Monitoring in the East Usambara Mountains: Proceedings of the second workshop. Departments of Botany/Zoology and Marine Biology, University of Dar es Salaam, Tanzania, pp 61-68.

Nelson DW and Sommers LE 1982 Total carbon, organic carbon and organic matter. In: Page AL (Ed.) Methods of soil analysis. Part 2: Chemical and microbiology properties. Agronomy monograph No. 9 (Second edition). Madson, U.S.A., pp. 539 - 579.

Olsen SR and Sommers LE 1982 Phosphorus. In: Page AL (Ed.) Methods of soil analysis. Part 2: Chemical and microbiology properties. Agronomy monograph no. 9 (Second edition). Madison, U.S.A., pp. $403-430$.

Rawls WJ, Pachepsky YA, Ritchie JC, Sobecki TM and Bloodworth H 2003 Effect of soil organic carbon on soil water retention. Geoderma 116: 61 - 76.

Rhoades JD 1982 Cation Exchange Capacity. In: Page AL (Ed) Methods of soil analysis. Part 2: Chemical and microbiological properties. Agronomy Monograph No. 9 (Second edition). Madison, pp. $149-158$.
Senzota RBM 2004 Ecological impact in Amani Nature Reserve following the rush for gold. In: Nikundiwe AM, Kabigumila JDL, Magingo FSS and Senzota RBM (Eds) Ecological Monitoring in the East Usambara Mountains: Proceedings of the second workshop. Departments of Botany/Zoology and Marine Biology, University of Dar es Salaam, Tanzania, pp $107-138$.

Senzota RBM and Mbago F 2006 Impact of gold mining on plants in East Usambaras. Field report, Departments of Botany/Zoology and Wildlife Conservation, University of Dar es Salaam. (in prep)

Shaka JM, Kabushemera W and Msangi A 1996 Soils and vegetation of Kambai Forest Reserve, Bombwera Division, Muheza District, Tanga. East Usambara Catchment Forest Project, Forestry and Beekeeping Division, Tanzania.

Shaka JM and Msangi A 1996 Soils and vegetation of Kwamarimba Forest Reserve, Bombwera Division, Muheza District, Tanga. East Usambara Catchment Forest Project, Forestry and Beekeeping Division, Tanzania.

Shaka JM and Mwanga H 1996 Soils and vegetation of Mlungui Proposed Forest Reserve, Maramba Division, Muheza District, Tanga. East Usambara Catchment Forest Project, Forestry and Beekeeping Division, Tanzania.

Swift RS 2001 Sequestration of carbon by soil. Soil Sci. 166: $858-871$.

Young A 1976 Tropical soil and soil survey. Cambridge University Press, Cambridge. 